\title{
The Microbial Metabolism of Thiophen-2-carboxylate
}

\author{
By ROGER E. CRIPPS \\ Milstead Laboratory of Chemical Enzymology, Shell Research Ltd., Sittingbourne, Kent, U.K.
}

(Received 12 October 1972)

\begin{abstract}
1. An organism was isolated by enrichment culture that was capable of using thiophen2-carboxylate as sole source of carbon, energy and sulphur for growth. 2. Analysis of the cellular protein after growth of the organism on thiophen-2-[14 C]carboxylate showed that only glutamate, proline and arginine were labelled. All the radioactivity in the glutamate was confined to $\mathrm{C}-1.3$. In the presence of $2.1 \mathrm{~mm}$-arsenite, suspensions of the organism converted thiophen-2-[14 $\mathrm{C}]$ carboxylate into ${ }^{14} \mathrm{C}$-labelled 2-oxoglutarate which had the same specific radioactivity as the starting material. 4. Cell-free extracts of the organism catalysed the release of ${ }^{14} \mathrm{CO}_{2}$ from thiophen-2-[ $\left[{ }^{14} \mathrm{C}\right]$ carboxylate. This activity was largely dependent on the presence of ATP and CoA and was stimulated by NAD ${ }^{+}$ and $\mathrm{Mg}^{2+}$. Inclusion of hydroxylamine resulted in the appearance of thiophen-2-carbohydroxamic acid, indicating that the ATP and CoA were involved in the formation of the CoA ester of thiophen-2-carboxylate. 5. High-speed centrifuging of cell-free extracts resulted in supernatants with decreased thiophen-2-carboxylate-degrading activity. Activity was restored by the addition of the high-speed pellet or by Methylene Blue. 6. The metabolism of the CoA ester of thiophen-2-carboxylate by cell-free extracts could be linked to the anaerobic reduction of Methylene Blue. 7. The sulphur atom of the thiophen nucleus was converted into sulphate by growing cultures and resting suspensions of the organism. 8. A degradative pathway is proposed involving the hydroxylation (at C-5) of the CoA ester of thiophen-2-carboxylate followed by further metabolism to 2-oxoglutarate and sulphate.
\end{abstract}

Although not of widespread occurrence, the thiophen nucleus is found in various situations in Nature. Thus fossil fuels, especially crude oil, have been shown to contain a wide variety of simple and complex thiophens (Challenger, 1959; Thompson et al., 1965; Druschel \& Sommers, 1967) and others, of plant and fungal origin, have been described (Stoll et al., 1967; Gianturco et al., 1966; Gronowitz, 1963).

Recent reports have shown that some thiophen derivatives can be degraded by micro-organisms. Yamada et al. (1968) reported the isolation of bacteria capable of utilizing dibenzothiophen as sole source of carbon, and further studies by the same workers revealed the nature of some of the metabolites that accumulated during the dissimilation (Kodama et al., 1970). Kurita et al. (1971) reported the microbial degradation of thiophen itself under anaerobic conditions. Attempts to demonstrate the aerobic dissimilation of thiophen have proved unsuccessful (Amphlett, 1968; Cripps, 1971).

Most information on the microbial degradation of the thiophen nucleus has been obtained from studies with a flavobacterium capable of utilizing thiophen2-carboxylate as a growth substrate (Amphlett, 1968; Amphlett \& Callely, 1969). It was suggested that the metabolism of this compound proceeded via 2-oxoglutarate with 5-hydroxythiophen-2-carboxylate as

Vol. 134 an intermediate. The sulphur atom of the nucleus was released as sulphide, which was not further metabolized. The present paper is also concerned with thiophen-2-carboxylate metabolism by an unidentified organism, designated Organism R1, and provides further insight into the way in which the thiophen nucleus can be degraded.

\section{Experimental}

\section{Maintenance and growth of Organism R1}

Organism R1, obtained by elective culture with thiophen-2-carboxylate as substrate, was maintained on Lab-Lemco slopes and in liquid thiophen-2carboxylate medium and stored at $4^{\circ} \mathrm{C}$. The liquid cultures were used as stock cultures for routine work and were subcultured monthly. The Lab-Lemco cultures were transferred at 6-monthly intervals and at each transfer fresh stock cultures were set up. The organism was grown at $30^{\circ} \mathrm{C}$ on a medium made by mixing sterile solutions having the following compositions (mM): solution $\mathrm{A}, \mathrm{KH}_{2} \mathrm{PO}_{4}, 67 ; \mathrm{NH}_{4} \mathrm{Cl}$, 30 ; adjusted to pH8.0 with $5 \mathrm{M}-\mathrm{NaOH}$; solution $\mathrm{B}$, $\mathrm{CaCO}_{3}, 0.125 ; \mathrm{ZnO}, 0.031 ; \mathrm{FeCl}_{3}, 0.125 ; \mathrm{MnCl}_{2}$, 0.031; $\mathrm{CuCl}_{2}, 0.006 ; \mathrm{CoCl}_{2}, 0.006 ; \mathrm{H}_{3} \mathrm{BO}_{3}, 0.006$; $\mathrm{HCl}, 0.97 ; \mathrm{MgCl}_{2}, 3.125 ; \mathrm{Na}_{2} \mathrm{MoO}_{4}, 0.006$; solution 
C, carbon and energy substrate in $67 \mathrm{~mm}$-sodium potassium phosphate buffer, $\mathrm{pH}$ 8.0. Then solutions A, B and C were mixed ( $3: 1: 1$, by vol.). The final concentrations of growth substrates in the medium were: thiophen-2-carboxylate, $4 \mathrm{~mm}$; furan-2-carboxylate, $4 \mathrm{~mm}$; succinate, $10 \mathrm{~mm}$. With substrates not containing sulphur, $\mathrm{NH}_{4} \mathrm{Cl}$ in solution $\mathrm{A}$ was replaced by $\left(\mathrm{NH}_{4}\right)_{2} \mathrm{SO}_{4}(15 \mathrm{mM})$. In all media, yeast extract was added to $0.005 \%(\mathrm{w} / \mathrm{v})$. Cultures for experimental purposes were inoculated $(5 \%, v / v)$ from cultures grown on a similar medium and were incubated with shaking at $30^{\circ} \mathrm{C}$ for $40 \mathrm{~h}$.

\section{Harvesting of cells}

Cells were harvested when in the exponential phase of growth by centrifuging $\left(15000 \mathrm{~g}\right.$ for $10 \mathrm{~min}$ at $\left.5^{\circ} \mathrm{C}\right)$. Cells were washed twice by resuspending in buffer (one-twentieth of the volume of the original culture) and centrifuging. The cell pellet was finally resuspended in the washing buffer, which was $67 \mathrm{mM}$ sodium-potassium phosphate (usually at $\mathrm{pH} 8.0$ ) for whole-cell studies $(5 \times$ pellet volume), and $50 \mathrm{~mm}$ Tris- $\mathrm{HCl}$ (usually at $\mathrm{pH} 7.75$ ) for the preparation of cell-free extracts ( $1 \times$ pellet volume).

\section{Preparation of cell-free extracts}

Cells were disrupted by two passages through a French pressure cell at $140 \mathrm{MPa}\left(20000 \mathrm{lb} / \mathrm{in}^{2}\right)$ at room temperature and the broken-cell preparations were clarified by centrifuging at $20000 \mathrm{~g}$ for $10 \mathrm{~min}$ at $5^{\circ} \mathrm{C}$. This preparation was designated $20000 \mathrm{~g}$ extract. Further fractionation, where necessary, was obtained by centrifuging in an MSE Superspeed 40. Extracts were maintained at $4^{\circ} \mathrm{C}$ and used within $24 \mathrm{~h}$.

\section{Respirometry}

$\mathrm{O}_{2}$-uptake rates were determined at $30^{\circ} \mathrm{C}$, either by conventional manometry or by using an oxygen electrode (Yellow Springs Instrument Co. Inc., Yellow Springs, Ohio, U.S.A.) connected to a cell of $7 \mathrm{ml}$ capacity.

\section{Determinations}

Sulphate was determined with barium chloroanilate by the method of Bertolacini \& Barney (1957) with all amounts decreased tenfold, sulphide by the method of Ellman (1959), phosphate by the method of Rockstein \& Herron (1951), and protein by the method of Lowry et al. (1951) with bovine plasma albumin (Armour Pharmaceutical Co. Ltd., Eastbourne, U.K.) as standard.

Thiophen-2-carboxylate concentrations in aqueous solutions at $\mathrm{pH} 7-8$ were calculated from their observed $E_{245}$ values by using an $\epsilon$ value of $8.6 \times$
$10^{3}$ litre $\cdot \mathrm{mol}^{-1} \cdot \mathrm{cm}^{-1}$, which had been determined experimentally. Concentrations of furan-2-carboxylate in aqueous solutions were also calculated from their observed $E_{245}$ values by using an $\epsilon$ value of $10.8 \times 10^{3} \mathrm{litre} \cdot \mathrm{mol}^{-1} \cdot \mathrm{cm}^{-1}$ (Trudgill, 1969). Growth of cultures was measured either by substrate disappearance or by $E_{570}$ and growth rates were obtained from these values. Dry weights of bacterial suspensions were determined after drying to constant weight at $105^{\circ} \mathrm{C}$.

\section{Spectrophotometry}

Absorbance measurements were obtained with Unicam SP. 600 and SP. 800 spectrophotometers (Unicam Instruments Ltd., Cambridge, U.K.). The SP. 800 was also used to record spectra and to follow enzymic reactions at constant wavelength. All measurements were made in cells of $1 \mathrm{~cm}$ light-path. I.r. spectra were obtained with a model 137 'Infracord' instrument (Perkin-Elmer Ltd., Beaconsfield, Bucks., U.K.).

\section{Buffers}

Phosphate buffers, normally used at a concentration of $67 \mathrm{mM}$, were prepared by adjusting solutions of $\mathrm{KH}_{2} \mathrm{PO}_{4}$ in water to the desired $\mathrm{pH}$ with $5 \mathrm{M}$ $\mathrm{NaOH}$. Tris $-\mathrm{HCl}$ buffers were prepared by adjusting $0.1 \mathrm{M}$-Tris to the desired $\mathrm{pH}$ with $0.1 \mathrm{M}-\mathrm{HCl}$ and diluting to $50 \mathrm{~mm}$.

\section{Radioactivity measurements}

Liquid-scintillation counting was carried out in a Packard Tri-Carb 3375 liquid-scintillation spectrometer. Non-aqueous samples were counted for radioactivity in a mixture containing $4 \mathrm{~g}$ of 2,5 -diphenyloxazole and $0.5 \mathrm{~g}$ of 1,4-bis-(5-phenyloxazol-2-yl)benzene per litre of toluene. Aqueous samples and Millipore filters were counted either in Bray's (1960) scintillator or in a mixture containing $4 \mathrm{~g}$ of 2,5 -bis(5-t-butylbenzoxazol-2-yl)thiophen per litre of $50 \%$ (v/v) toluene in methanol. Radioactive areas on chromatograms were located by a Packard model 7201 radiochromatogram scanner.

\section{Chromatography and electrophoresis}

T.l.c. was performed on $0.1 \mathrm{~mm}$-thick precoated silica gel plates containing fluorescence indicator $(E$. Merck, Darmstadt, Germany) which were activated at $105^{\circ} \mathrm{C}$ for $30 \mathrm{~min}$ before use. Larger quantities of material were separated on 'Preparative' precoated silica plates (Merck), which were washed with ethanol before use. The following solvents were used: chloroform-methanol-acetic acid (32:2:1, by vol.) (TL 1); ethanol- $\mathrm{NH}_{3}$ (sp.gr. 0.880$)$-water $(8: 1: 1$, by vol.) 
(TL 2); butan-1-ol-ethanol-water $(5: 1: 4$, by vol.; upper layer; Cavallini et al., 1949) (TL 3); 2-methylbutan-2-ol-ethanol-water $(5: 1: 4$, by vol.; upper layer; Altmann et al., 1951) (TL 4); butan-1-ol$\mathrm{NH}_{3}$ (sp.gr. 0.880) $(19: 1, \mathrm{v} / \mathrm{v}$; Hockenhull et al., 1953) (TL 5); 2-methylbutan-2-ol-0.25 $\mathrm{M}-\mathrm{NH}_{3}$ (20:1, $\mathrm{v} / \mathrm{v}$; Dancis et al., 1963) (TL 6); ethyl formate-light petroleum (b.p. $\left.60-80^{\circ} \mathrm{C}\right)$-propionic acid $(14: 26: 3$, by vol.; Ronkainen, 1963) (TL 7); benzene-dioxanacetic acid (90:25:4, by vol.; Petrowitz \& Pastuska, 1962) (TL 8); benzene - methanol - acetic acid (45:8:4, by vol.; Petrowitz \& Pastuska, 1962) (TL 9); butan-1-ol saturated with water (Price \& Campbell, 1957) (TL 10); and propan-2-ol-butan-1-ol-1 Macetic acid (9:8:3, by vol.; Price \& Campbell, 1957) (TL 11).

Samples of protein hydrolysate containing radioactively labelled amino acids were examined by descending paper chromatography at $20^{\circ} \mathrm{C}$ and by paper electrophoresis by using a Pherograph 64 (The Northern Media Supply Co. Ltd., Hull, U.K.) on Whatman $3 \mathrm{MM}$ paper at $-5^{\circ} \mathrm{C}$. The amino acids in hydrolysed protein were separated by electrophoresis in pyridine-acetic acid-water (20:1:180, by vol.), pH6.5, for $1 \mathrm{~h}$ at $40 \mathrm{~V} / \mathrm{cm}$ (Ryle et al., 1955). The radioactive areas were located and the labelled amino acids eluted with water. The eluates were concentrated by evaporation under reduced pressure at $45^{\circ} \mathrm{C}$ and the labelled amino acids were further purified as follows: for glutamate, chromatography on Whatman No. 1 in liquified phenol-butan-1-ol-acetic acidwater (10:5:2:10, by vol.) (Leggett Bailey, 1967); for proline, chromatography on Whatman 3MM paper in propan-1-ol-water $(4: 1, \mathrm{v} / \mathrm{v})$ (Kemble \& MacPherson, 1954) followed by elution as described above and chromatography as for glutamate; for arginine, electrophoresis in $0.05 \mathrm{M}$-sodium borate buffer, $\mathrm{pH} 9.2$, for $2 \mathrm{~h}$ at $40 \mathrm{~V} / \mathrm{cm}$ (Gross, 1955) followed by elution and electrophoresis in pyridineacetic acid-water (2:1:97, by vol.), pH 5.2, for $1.5 \mathrm{~h}$ at $33 \mathrm{~V} / \mathrm{cm}$ (Leggett Bailey, 1967). These procedures resulted in the separation of the named amino acids from all other ninhydrin-positive compounds present.

\section{Detection of compounds on chromatograms}

Aromatic compounds were detected with a u.v. lamp (Hanovia Ltd., Slough, Bucks., U.K.), hydroxamic acids by $\mathrm{FeCl}_{3}[5 \%$ (w/v) in ethanol], $N$-ethylmaleimide derivatives by the spray reagent of Benesch et al. (1956) and amino acids by ninhydrin [0.2\% $(w / v)$ in acetone].

\section{Growth on thiophen-2-[14 C]carboxylate}

Organism R1 was grown on 1 litre of medium containing thiophen-2-[14 $\mathrm{C}]$ carboxylate $(4 \mathrm{mM}$,
$8.3 \mu \mathrm{Ci} / \mathrm{mmol})$ and $\mathrm{NaHCO}_{3}(40 \mathrm{~mm})$. The growth vessel was a 2 litre conical flask fitted with a gasbubbling attachment, a gas outlet and a dropping funnel all connected to the flask by ground-glass joints. The culture was aerated with a stream of $\mathrm{CO}_{2}$ free air and metabolically produced $\mathrm{CO}_{2}$ was removed from the exhaust gases by passage through $100 \mathrm{ml}$ of $2 \mathrm{M}-\mathrm{NaOH}$ in a Drechsel bottle filled with glass beads. When adequate growth had occurred, $10 \mathrm{ml}$ of conc. $\mathrm{HCl}$ was added to the culture vessel and $\mathrm{CO}_{2}$-free air passed for a further $1.5 \mathrm{~h}$. Cells were centrifuged from the culture and washed once at $4^{\circ} \mathrm{C}$ with $170 \mathrm{ml}$ of $67 \mathrm{~mm}$-phosphate buffer, pH8.0. The washings and the culture supernatant were combined (supernatant fraction).

The radioactively labelled cells were fractionated by a modification of the method of Somerville (1965). (1) The washed cells were suspended in $40 \mathrm{ml}$ of aq. $75 \%(\mathrm{v} / \mathrm{v})$ ethanol, maintained at $50^{\circ} \mathrm{C}$ for $20 \mathrm{~min}$ and centrifuged $(20000 \mathrm{~g}, 15 \mathrm{~min})$. The supernatant was designated the 'ethanol-soluble fraction'. (2) The pellet from step (1) was suspended in $40 \mathrm{ml}$ of $5 \%$ (v/v) trichloroacetic acid and maintained at $100^{\circ} \mathrm{C}$ for $30 \mathrm{~min}$. The suspension was centrifuged $(20000 \mathrm{~g}$, $30 \mathrm{~min}$ ) and the pellet washed with $20 \mathrm{ml}$ of water. Supernatant and washings were designated the 'trichloroacetic acid-soluble fraction'. (3) The residue from step (2) was washed with $40 \mathrm{ml}$ of $50 \mathrm{mM}-\mathrm{HCl}$ in ethanol and then with ether, the washings being discarded, and was finally suspended in $8.5 \mathrm{ml}$ of water. This suspension was designated the 'protein fraction'. Portions of this fraction were hydrolysed in $6 \mathrm{M}-\mathrm{HCl}$ at $105^{\circ} \mathrm{C}$ for $17 \mathrm{~h}$ in a sealed glass tube. The hydrolysate was filtered and the filtrate evaporated to dryness under decreased pressure at $45^{\circ} \mathrm{C}$. The residue was dissolved in water and again evaporated to dryness. This cycle was thrice repeated. The last traces of $\mathrm{HCl}$ were removed by $\mathrm{NaOH}$ pellets in a vacuum desiccator. The radioactively labelled amino acids were identified and purified as described above.

The specific radioactivities of the labelled amino acids were determined in a separate experiment in which a sample of the 'protein fraction' $(2.5 \mathrm{ml}$, $1.1 \times 10^{5}$ c.p.m.) was hydrolysed and the whole hydrolysate subjected to electrophoresis on Whatman $3 \mathrm{MM}$ paper in pyridine-acetic acid-water $(20: 1: 180$, by vol.) for $1 \mathrm{~h}$ at $40 \mathrm{~V} / \mathrm{cm}$ (Ryle et al., 1955) to separate proline, arginine and glutamate. The radioactive areas were eluted with water and the eluate volume was made up to $5 \mathrm{ml}$. Samples $(0.2 \mathrm{ml})$ of each were counted for radioactivity in Bray's (1960) scintillator. The concentrations of the amino acids in the eluates were determined by passing $0.5 \mathrm{ml}$ samples through a Technicon automatic amino acid analyser (Technicon Instruments Co. Ltd., Chertsey, Surrey, U.K.) with norleucine as an internal standard and by computing the concentration from the areas

Vol. 134 
(peak height $\times$ peak width at half-height) of the peaks produced by the analyser-recorder.

\section{Decarboxylation of $\left[{ }^{14} \mathrm{C}\right]$ glutamate}

Purified $\left[{ }^{14} \mathrm{C}\right]$ glutamate (approx. $2 \mu \mathrm{mol}$ ), obtained by growth of Organism R1 on thiophen-2-[14 $\mathrm{C}]$ carboxylate, was dissolved in $2 \mathrm{ml}$ of a solution containing $120 \mu \mathrm{mol}$ of unlabelled glutamic acid and C-1 was removed as $\mathrm{CO}_{2}$ by the procedure of Hoare (1963). Evolved ${ }^{14} \mathrm{CO}_{2}$ was flushed from the reaction flasks with a stream of $\mathrm{N}_{2}$ for $20 \mathrm{~min}$ and collected in $5 \mathrm{ml}$ of $2 \mathrm{M}-\mathrm{NaOH}$. This solution was added to $5 \mathrm{ml}$ of $30 \mathrm{~mm}-\mathrm{BaCl}_{2}$ along with $30 \mu \mathrm{mol}$ of carrier $\mathrm{Na}_{2} \mathrm{CO}_{3}$ and precipitated $\mathrm{BaCO}_{3}$ was collected on a $25 \mathrm{~mm}$ type HA Millipore filter. The filter was placed in a scintillator vial and counted for radioactivity in $10 \mathrm{ml}$ of scintillator.

\section{Determination of thiophen-2-carboxylate degradation in cell-free extracts}

Thiophen-2-carboxylate degradation by cell-free extracts was determined by the release of ${ }^{14} \mathrm{CO}_{2}$ from thiophen-2-[14C]carboxylate. Assays were performed in double-side-arm Warburg vessels. The basal reaction mixture comprised ( $\mu \mathrm{mol})$ : Tris $-\mathrm{HCl}$ buffer, pH 7.75, 60; ATP, $10 ; \mathrm{CoA}, 0.26 ; \mathrm{NAD}^{+}, 2.5 ; \mathrm{MgCl}_{2}$, 10 ; and $20000 \mathrm{~g}$ extract $(4.5-8.0 \mathrm{mg}$ of protein) in a total volume of $1.4 \mathrm{ml}$, and was contained in the main compartment of the flasks. Reaction was initiated by the addition of thiophen-2-[14 $\mathrm{C}]$ carboxylate $(1.52 \mu \mathrm{mol}, 19 \mu \mathrm{Ci} / \mathrm{mmol}$, in $0.1 \mathrm{ml}$ of $67 \mathrm{~mm}$-phosphate buffer, pH8.0) from one side arm and the mixture was incubated in a shaking bath at $30^{\circ} \mathrm{C}$ for $1 \mathrm{~h}$. The reaction was terminated by the addition of $0.2 \mathrm{ml}$ of $2 \mathrm{M}-\mathrm{HCl}$ from the other side arm. Evolved ${ }^{14} \mathrm{CO}_{2}$ was collected from the reaction flasks and assayed for radioactivity as described above. All determinations were carried out in duplicate.

\section{Enzyme assays}

Adenosine triphosphatase activity was determined by the release of $\mathbf{P}_{\mathbf{i}}$ from incubation mixtures containing, in $1 \mathrm{ml}, 50 \mu \mathrm{mol}$ of Tris- $\mathrm{HCl}$ buffer (pH8.0), $4 \mu \mathrm{mol}$ of ATP and $4 \mathrm{mg}$ of $20000 \mathrm{~g}$-extract protein. The reaction was terminated after $1 \mathrm{~h}$ at $30^{\circ} \mathrm{C}$ by the addition of $1 \mathrm{ml}$ of $5 \%(\mathrm{w} / \mathrm{v}) \mathrm{HClO}_{4}$. The $\mathrm{P}_{1}$ was determined in $0.2 \mathrm{ml}$ samples of the clear supernatant.

NADH oxidase activity was measured at $20^{\circ} \mathrm{C}$ by the decrease in $E_{340}$ in incubation mixtures containing, in $3 \mathrm{ml}, 150 \mu \mathrm{mol}$ of Tris- $\mathrm{HCl}$ buffer (pH7.75), $0.3 \mu \mathrm{mol}$ of NADH and $1 \mathrm{mg}$ of $20000 \mathrm{~g}$-extract protein.

\section{Determination of the metabolism of the CoA ester of thiophen-2-carboxylate}

The metabolism of the CoA ester of thiophen-2carboxylate was assayed by its stimulation of Methylene Blue reduction. The reaction was carried out in $10 \mathrm{~mm}$-light-path silica cuvettes fitted with a side arm and sealed with Subaseal rubber stoppers. The cuvette contained, in $2.8 \mathrm{ml}$, Tris- $\mathrm{HCl}$ buffer $(130 \mu \mathrm{mol}, \mathrm{pH} 7.75), \mathrm{NAD}^{+}(2.5 \mu \mathrm{mol}), \mathrm{MgCl}_{2}$ $(10 \mu \mathrm{mol})$, Methylene Blue $(62.5 \mathrm{nmol})$ and extract $(0.93 \mathrm{mg}$ of protein). Extract was prepared by passing $20000 \mathrm{~g}$ extract through a column $(12.5 \mathrm{~cm} \times$ $2.5 \mathrm{~cm}$ ) of Sephadex G-25, equilibrated and eluted with $50 \mathrm{~mm}$-Tris- $\mathrm{HCl}$ buffer, $\mathrm{pH} 7.75$; the material eluted with the void volume was collected and used directly. The mixture was gassed with $\mathrm{N}_{2}$ after the addition of $1 \mu 1$ of Silicone MS anti-foam. After the endogenous rate of Methylene Blue reduction had been determined, a solution of the CoA ester $(0.2 \mathrm{ml}$, containing approx. $19 \mathrm{nmol}$; also gassed with $\mathrm{N}_{2}$ ) was added from the side arm to initiate the reaction, which was followed at $665 \mathrm{~nm}$. The molar extinction coefficient of Methylene Blue at $665 \mathrm{~nm}$ was taken to be $4.18 \times 10^{4}$ litre $\cdot \mathrm{mol}^{-1} \cdot \mathrm{cm}^{-1}$.

\section{Conversion of thiophen-2-carboxylate into 2-oxo- glutarate under anaerobic conditions}

The formation of 2-oxoglutarate from thiophen-2carboxylate under anaerobic conditions was shown in reaction mixtures containing, in $2.9 \mathrm{ml}$, Tris $-\mathrm{HCl}$ buffer pH7.75 $(150 \mu \mathrm{mol})$, ATP $(20 \mu \mathrm{mol})$, CoA $(0.52 \mu \mathrm{mol}), \mathrm{MgCl}_{2}(20 \mu \mathrm{mol})$, Methylene Blue $(1.6 \mu \mathrm{mol})$, sodium arsenite $(6 \mu \mathrm{mol}), 20000 \mathrm{~g}$ extract (7.6 mg of protein) which had been treated with Sephadex G-25 as described above, and anti-foam $(1 \mu 1)$. The reaction was carried out in Thunberg tubes and the mixture was gassed with $\mathrm{N}_{2}$ for $5 \mathrm{~min}$. Thiophen-2- $\left[{ }^{14} \mathrm{C}\right]$ carboxylate $(1.1 \mu \mathrm{mol}, 22 \mu \mathrm{Ci} /$ $\mathrm{mmol}$, in $0.1 \mathrm{ml}$ of Tris- $\mathrm{HCl}$ buffer, $\mathrm{pH} 7.75$ ) was added from the stopper of the evacuated Thunberg tube to start the reaction, and the mixture was incubated for $100 \mathrm{~min}$ at $30^{\circ} \mathrm{C}$. The reaction was terminated with $3 \mathrm{ml}$ of $10 \%$ (w/v) $\mathrm{HClO}_{4}$ and the 2,4-dinitrophenylhydrazone of 2-oxoglutarate was formed by the addition of $\frac{1}{3}$ vol. of $0.1 \%(w / v) ~ 2,4-$ dinitrophenylhydrazine in $2 \mathrm{M}-\mathrm{HCl}$, extracted into ethyl acetate and separated from residual thiophen2-carboxylate by chromatography in solvent TL 3 .

\section{Preparation of thiophen-2-[14 C]carboxylic acid}

Thiophen-2-carboxylate labelled with ${ }^{14} \mathrm{C}$ in the carboxyl group was prepared by the reaction of 2-thienyl-lithium with ${ }^{14} \mathrm{CO}_{2}$. 2-Thienyl-lithium was prepared by the reaction of $n$-butyl-lithium with thiophen by the method of Benkeser \& Currie (1948) 
and $15 \mathrm{mmol}$ wascarboxylated with ${ }^{14} \mathrm{CO}_{2}$ in a vacuum apparatus as described by Murray \& Williams (1958). The ${ }^{14} \mathrm{CO}_{2}$ was generated from $\mathrm{Ba}^{14} \mathrm{CO}_{3}(10 \mathrm{mmol}$, $436 \mu \mathrm{Ci} / \mathrm{mmol}$ ) obtained from The Radiochemical Centre, Amersham, Bucks., U.K. The brown residue resulting from this procedure was dissolved in water and decolorized by boiling with charcoal (Norit NK) for $30 \mathrm{~min}$. The charcoal was removed by filtration and on cooling thiophen-2-carboxylate crystallized from the filtrate. The mother liquor was acidified and extracted with ether, the ether was evaporated and the residue crystallized from a small volume of water. The two batches of crystals were combined, giving a yield of $645 \mathrm{mg}(50 \%$ with respect to $\left.\mathrm{Ba}^{14} \mathrm{CO}_{3}\right)$. Unlabelled thiophen-2-carboxylate $(2.5 \mathrm{~g})$ was added to the labelled product and the mixture was again treated with charcoal and recrystallized from water. The specific radioactivity of the material was $83 \mu \mathrm{Ci} / \mathrm{mmol}$. It was shown to be radiochemically pure by t.l.c. in various solvents.

\section{Preparation of thiophen-2-carbohydroxamic acid}

Thiophen-2-carboxylate $(8 \mathrm{~g})$ was esterified by refluxing with $35 \mathrm{ml}$ of methanol containing $0.9 \mathrm{ml}$ of conc. $\mathrm{H}_{2} \mathrm{SO}_{4}$ for $3.5 \mathrm{~h}$. Excess of methanol was removed by distillation and the residue extracted with ether. The ether was washed with $10 \%(w / v) \mathrm{NaHCO}_{3}$ until $\mathrm{CO}_{2}$ evolution ceased and was then washed with water. Methyl thiophen-2-carboxylate was obtained by removing the ether by distillation, after drying with anhydrous $\mathrm{Na}_{2} \mathrm{SO}_{4}$. Free hydroxylamine was prepared by dissolving $2.5 \mathrm{~g}$ of hydroxyammonium chloride and $1.46 \mathrm{~g}$ of $\mathrm{NaOH}$ in $40 \mathrm{ml}$ of methanol and the $\mathrm{NaCl}$ formed was filtered off. To this solution, $3 \mathrm{ml}$ of methyl thiophen-2-carboxylate was added together with a solution of $1.25 \mathrm{~g}$ of $\mathrm{NaOH}$ in $15 \mathrm{ml}$ of methanol and the mixture was left at room temperature for $22 \mathrm{~h}$. Conc. $\mathrm{HCl}(2 \mathrm{ml})$ was added, precipitated $\mathrm{NaCl}$ removed by filtration and the filtrate evaporated to dryness at $35^{\circ} \mathrm{C}$ under reduced pressure. The residue was crystallized from water and recrystallized from toluene [yield $1.4 \mathrm{~g} ; \mathrm{m} . \mathrm{p}$. $119^{\circ} \mathrm{C}$ (literature value, $123-124.5^{\circ} \mathrm{C}$; Jones \& Hurd, 1921)].

\section{Preparation of the CoA ester of thiophen-2-carboxylate}

CoA was made to react with the $N$-hydroxysuccinimide ester of thiophen-2-carboxylate, the latter being prepared by the method of Lapidot et al. (1967) by mixing equimolar amounts of $N$-hydroxysuccinimide, thiophen-2-carboxylate and dicyclohexylcarbodi-imide in ethyl acetate. A solution of CoA $(19.5 \mu \mathrm{mol}$ in $0.8 \mathrm{ml}$ of water) containing $30 \mu \mathrm{mol}$ of sodium thioglycollate was adjusted to $\mathrm{pH} 8.0$ with $\mathrm{NaHCO}_{3}$ and mixed with a solution of the $N$-hydroxysuccinimide ester $(60 \mu \mathrm{mol}$ in $1 \mathrm{ml}$ of freshly distilled tetrahydrofuran). The mixture was stirred at room temperature for $2.5 \mathrm{~h}$. Tetrahydrofuran was removed in a stream of $\mathrm{N}_{2}$, the mixture was cooled in ice and the precipitate that formed was filtered off. The filtrate was made up to $5 \mathrm{ml}$ with $50 \mathrm{~mm}-\mathrm{Tris}-\mathrm{HCl}$ buffer, pH7.5, and applied to a column $(28 \mathrm{~cm} \times$ $1.6 \mathrm{~cm}$ ) of DEAE-cellulose (DE-52, Whatman) equilibrated with the same buffer. The column was eluted at $4^{\circ} \mathrm{C}$ with a linear $\mathrm{NaCl}$ gradient, generated from $700 \mathrm{ml}$ of the Tris $-\mathrm{HCl}$ buffer and $700 \mathrm{ml}$ of $0.3 \mathrm{M}-\mathrm{NaCl}$ in the same buffer, and the eluate was monitored at $254 \mathrm{~nm}$ with a Uvicord II spectrophotometer (LKB-Produkter AB, Bromma 1, Sweden). The mixture was resolved into 13 u.v.-absorbing components and the major peak was identified as the CoA ester of thiophen-2-carboxylate by the following criteria: (a) hydrolysis in $0.1 \mathrm{M}-\mathrm{NaOH}$ for $15 \mathrm{~min}$ at $50^{\circ} \mathrm{C}$ resulted in the appearance of a thiol group (Ellman's reagent); (b) alkaline hydrolysis [as in (a)] followed by acidification and ether extraction resulted in an aqueous residue which, at $\mathrm{pH} 2$ and $\mathrm{pH} 12$, possessed the spectral characteristics of a 9-substituted adenine derivative (Beaven et al., 1955). The ether extract contained thiophen-2-carboxylate as shown by its t.l.c. properties in solvents TL 1 and TL 2. No further purification was attempted and hence $\mathrm{NaCl}$ was present in the preparation at a concentration of approx. $0.2 \mathrm{M}$. The concentration of the CoA ester was determined by measuring the $P_{1}$ released after digestion of the sample as described by Chen et al. (1956).

\section{Chemical reagents}

Chemical reagents and solvents were of the best available commercial grade and were obtained from either Hopkin and Williams Ltd., London E.C.1, U.K., British Drug Houses Ltd., Poole, Dorset, U.K., or Koch-Light Laboratories Ltd., Colnbrook, Bucks., U.K. CoA, NAD ${ }^{+}$, NADH, glutamate dehydrogenase and alcohol dehydrogenase were obtained from C.F. Boehringer und Soehne G.m.b.H., Mannheim, Germany; ATP and Methylene Blue were from Sigma (London) Chemical Co. Ltd., Kingstonon-Thames, Surrey, U.K.; thiophen-2-carboxylate, barium chloroanilate and 2-oxoglutarate were from Koch-Light Laboratories Ltd.; furan-2-carboxylate, thiophen-2,5-dicarboxylic acid, 2,4-dinitrophenylhydrazine, silicone MS anti-foam and sodium arsenite were from Hopkin and Williams Ltd.; $N$-ethyl maleimide was from British Drug Houses Ltd.; thiophen-3-carboxylic acid was from $K$ \& $K$ Laboratories Inc., Plainview, N.Y., U.S.A.; and 5,5'-dithiobis-(2-nitrobenzoic acid) was from Ralph N. Emanuel Ltd., Alperton, Middx., U.K. $N$-Hydroxysuccinimide was a kind gift from Mr. J. P. Kitcher and Dr. P. W. Trudgill (University College of Wales, Aberystwyth, Cards., U.K.). $\mathrm{O}_{2}$-free $\mathrm{N}_{2}$ (The British

Vol. 134 
Oxygen Co. Ltd., Greenwich, London S.E.10, U.K.) was further purified by successive passage through solutions of alkaline pyrogallol and chromous sulphate contained in a bead tower. The latter reagent was prepared by passing a saturated solution of chrome alum in $2 \mathrm{M}-\mathrm{HCl}$ over zinc wire (Vogel, 1961). The purified gas was used to obtain anaerobic conditions in enzymic reactions.

\section{Results}

\section{Oxidative activities of whole cells}

Organism R1 was capable of utilizing thiophen-2carboxylate as sole source of carbon, sulphur and energy for growth. In addition, thiophen-2,5-dicarboxylic acid and furan-2-carboxylate acted as substrates but thiophen, thiophen-3-carboxylate and benzo[b]thiophen-2-carboxylate did not support growth. The generation time of the organism at $30^{\circ} \mathrm{C}$ with thiophen-2-carboxylate varied with different cultures within the range 4.0-6.5 h. The $\mathrm{O}_{2}$ uptake rates with thiophen-2-carboxylate of freshly harvested cells, grown on this substrate, were also somewhat variable within the range $65-90 \mu 1 / \mathrm{h}$ per $\mathrm{mg}$ dry wt.

The ability of washed cell suspensions to oxidize thiophen-2-carboxylate was inducible (Table 1). Growth of the organism on succinate resulted in a low but detectable oxidative activity with respect to thiophen-2-carboxylate, which was increased 12-fold by growth on this compound. In addition, cells grown on thiophen-2-carboxylate were able to oxidize furan-2-carboxylate at a rate in excess of that shown by succinate-grown cells. However, after growth on furan-2-carboxylate cells showed little ability to oxidize thiophen-2-carboxylate. As well as the growth substrate, cells grown on thiophen-2-carboxylate were able to oxidize thiosulphate and sulphide at rates greatly in excess of those shown by succinate-grown cells. Sulphite was not oxidized at a significant rate (Table 1).

Inducible activities in Organism R1 were also determined after growth in succinate medium supplemented with $0.5 \mathrm{~mm}$-thiophen-3-carboxylate, as this latter compound has been reported to act as a nonmetabolizable inducer of thiophen-2-carboxylate oxidation (Amphlett, 1968). The results showed that thiophen-3-carboxylate was able to induce both thiophen-2-carboxylate- and furan-2-carboxylateoxidizing activities to a similar extent (27 and $34 \mu \mathrm{l}$ of $\mathrm{O}_{2} / \mathrm{h}$ per $\mathrm{mg}$ dry wt. respectively). No induction of thiosulphate-oxidizing activity was observed. Thiophen-3-carboxylate appears to be a genuine nonmetabolizable inducer, since its concentration in the growth medium did not decrease during the period of the experiment. In similar studies, in which cultures were incubated for periods up to 10 days, no metabolism of this compound was ever observed.

Thiosulphate-oxidizing activity in cells grown on succinate alone was virtually undetectable. Large quantities of cells were needed before any stimulation of $\mathrm{O}_{2}$ uptake with thiosulphate could be observed and the rate found was never greater than $1 \mu l$ of $\mathrm{O}_{2} / \mathrm{h}$ per mg dry wt. (Table 1 ). A substantial increase in this activity ( $48 \mu \mathrm{l}$ of $\mathrm{O}_{2} / \mathrm{h}$ per mg dry wt.) was found with cells from cultures grown on succinate to which $\mathrm{Na}_{2} \mathrm{~S}(1 \mathrm{mM})$ was added as the source of sulphur. These cells showed no thiophen-2-carboxylate- or furan-2-carboxylate-oxidizing abilities above the non-induced value.

\section{Growth of the organism on thiophen-2-[14C]carboxy- late}

Growth on ${ }^{14} \mathrm{C}$-labelled thiophen-2-carboxylate and fractionation of the cells obtained were carried

\section{Table 1. Oxidative activities of Organism $R 1$ after growth on various substrates}

The oxygen-electrode cell was filled with $67 \mathrm{~mm}$-phosphate buffer, pH8.0, equilibrated at $30^{\circ} \mathrm{C}$ and cell suspension was added. Reactions were started by the addition of substrate. Amounts of cell suspension added were: succinate-grown, $6.8 \mathrm{mg}$; thiophen-2-carboxylate-grown, $3.0 \mathrm{mg}$; furan-2-carboxylate-grown, $2.5 \mathrm{mg}$. Values of $\mathrm{O}_{2}$ uptake were corrected for the uptake of $\mathrm{O}_{2}$ in the absence of substrate $(10-12 \mu \mathrm{l} / \mathrm{h}$ per $\mathrm{mg}$ dry wt.).

$\mathrm{O}_{2}$ uptake ( $\mu \mathrm{l} / \mathrm{h}$ per $\mathrm{mg}$ dry wt.)

\begin{tabular}{|c|c|c|c|c|c|}
\hline Substrate and amount & Cells grown on & $\cdots$ & Thiophen-2-carboxylate & Succinate & Furan-2-carboxylate \\
\hline $\begin{array}{l}\text { Thiophen-2-carboxylate } \\
(2.5 \mu \mathrm{mol})\end{array}$ & & & 78 & 6 & 3 \\
\hline $\begin{array}{l}\text { Furan-2-carboxylate } \\
\qquad(2.5 \mu \mathrm{mol})\end{array}$ & & & 37 & 7 & 70 \\
\hline $\mathrm{Na}_{2} \mathrm{~S}_{2} \mathrm{O}_{3}(2.5 \mu \mathrm{mol})$ & & & 98 & 1 & - \\
\hline $\mathrm{Na}_{2} \mathrm{~S}(0.5 \mu \mathrm{mol})$ & & & 80 & 3 & - \\
\hline $\mathrm{Na}_{2} \mathrm{SO}_{3}(1.25 \mu \mathrm{mol})$ & & & 7 & 15 & - \\
\hline
\end{tabular}


Table 2. Distribution of radioactivity in various cellular fractions after growth of Organism $R 1$ on thiophen-2$\left[{ }^{14} \mathrm{C}\right]$ carboxylate

Growth of the culture and fractionation of the cells are described in the Experimental section. Radioactivity in each fraction was determined by counting $0.1 \mathrm{ml}$ samples in Bray's (1960) scintillator. Recovery of radioactivity was $65.4 \%$ of the $1.7 \times 10^{7}$ c.p.m. supplied.

Fraction

Supernatant

Acid-volatile compounds

'Ethanol-soluble'

'Trichloroacetic acidsoluble'

'Protein'

\section{Contents}

Unused thiophen-2-carboxylate (and products?)

$\mathrm{CO}_{2}$

Lipid, soluble protein and low-molecularweight compounds

Nucleic acid

Protein
Total radioactivity (c.p.m.)

$2.5 \times 10^{6}$

$8.2 \times 10^{6}$

$1.4 \times 10^{4}$

$2.0 \times 10^{4}$

$3.8 \times 10^{5}$
$\%$ of recovered radioactivity

22.6

73.8

0.13

0.18

3.4 out as described above. The growth medium was supplemented with $\mathrm{NaHCO}_{3}(40 \mathrm{mM})$ to dilute any ${ }^{14} \mathrm{CO}_{2}$ released during thiophen-2-carboxylate metabolism so that the amount of radioactivity taken up by possible carboxylation reactions would be decreased. The distribution of the radioactivity in the various fractions is shown in Table 2. Most of the radioactivity was recovered as ${ }^{14} \mathrm{CO}_{2}$ with smaller amounts in the supernatant and 'protein fraction'. Other fractions showed very little radioactivity. The low recovery of radioactivity is attributed to incomplete collection of ${ }^{14} \mathrm{CO}_{2}$. Analysis of hydrolysates of the 'protein fraction' revealed that all of the radioactivity of this fraction was contained in glutamate, proline and arginine; no other amino acid contained detectable radioactivity. The specific radioactivities of the labelled compounds were (d.p.m./nmol) glutamate, 17.2, proline, 16.6, and arginine, 19.3, which were very close to that of the thiophen-2carboxylate on which the cells were grown (18.5 d.p.m./nmol). Removal of C-1 of the purified $\left[{ }^{14} \mathrm{C}\right]$ glutamate as $\mathrm{CO}_{2}$ by chloramine-T resulted in the release of all the radioactivity, leaving nonradioactive succinic semialdehyde.

\section{Effect of arsenite on thiophen-2-carboxylate oxidation}

The rate of $\mathrm{O}_{2}$ uptake of thiophen-2-carboxylategrown cells with thiophen-2-carboxylate was decreased by $68 \%$ in the presence of $2.1 \mathrm{mM}$-arsenite and the amount of $\mathrm{O}_{2}$ consumed per mol of substrate was decreased from $3.8 \mathrm{~mol}$ to $1.8 \mathrm{~mol}$. Under these conditions 2-oxoglutarate accumulated. The 2-oxoglutarate was identified by chromatographic comparison of its 2,4-dinitrophenylhydrazone with authentic 2-oxoglutarate 2,4-dinitrophenylhydrazone, which showed that they had identical $R_{F}$ values in solvents TL 3, TL 4, TL 5, TL 6 and TL 7. In addition, the spectra
Table 3. Cofactor requirements of the cell-free thiophen-2-carboxylate-degrading system of Organism $R 1$

Determinations of thiophen-2-carboxylate degradation were carried out as described in the Experimental section with the omissions noted below. Each assay contained $7 \mathrm{mg}$ of $20000 \mathrm{~g}$-extract protein.

$\begin{array}{cc}\begin{array}{c}\text { Omissions from basal } \\ \text { reaction mixture }\end{array} & \begin{array}{c}{ }^{14} \mathrm{CO}_{2} \text { evolved } \\ \text { (c.p.m./h) }\end{array} \\ \text { None } & 2774 \\ \text { ATP } & 237 \\ \text { CoA } & 691 \\ \mathrm{NAD}^{+} & 1405 \\ \mathrm{MgCl}_{2} & 2232\end{array}$

of the two derivatives in $1 \mathrm{M}-\mathrm{NaOH}$ were identical. When cells $(80 \mathrm{mg}$ dry wt.) were incubated with thiophen $-2-\left[{ }^{14} \mathrm{C}\right]$ carboxylate $(22.6 \mu \mathrm{mol}, 7.5 \mu \mathrm{Ci} /$ $\mathrm{mmol}$ ) in $18 \mathrm{ml}$ of $67 \mathrm{~mm}$-phosphate buffer (pH8.0) containing $2.1 \mathrm{~mm}$-arsenite, 2-oxoglutarate was the only radioactive compound that accumulated. The material was purified by t.l.c. of its 2,4-dinitrophenylhydrazone in solvent TL 3 , followed by elution with ethyl acetate and further purification by chromatography in solvent TL 7 . The specific radioactivity of the purified material was determined by eluting with $1 \mathrm{M}-\mathrm{NaOH}$ and measuring $E_{416}\left(\epsilon=14.1 \times 10^{3}\right.$ litre $\left.\cdot \mathrm{mol}^{-1} \cdot \mathrm{cm}^{-1}\right)$ to determine the concentration and then by counting radioactivity in Bray's (1960) scintillator. The specific radioactivity found $(4527 \pm$ 350 c.p.m. $/ \mu \mathrm{mol}$ ) corresponded very closely to that of the thiophen-2-carboxylate used as substrate $(4475 \pm 134$ c.p.m. $/ \mu \mathrm{mol})$, indicating that the 2-oxoglutarate was formed directly from thiophen-2carboxylate. 


\section{Metabolism of thiophen-2-carboxylate by cell-free extracts}

Cell-free extracts of the thiophen-2-carboxylategrown organism were capable of catalysing the breakdown of thiophen-2- $\left[{ }^{14} \mathrm{C}\right]$ carboxylic acid with the concomitant evolution of ${ }^{14} \mathrm{CO}_{2}$. This activity was largely dependent on the presence of ATP and CoA in the incubation mixture and was also stimulated by $\mathrm{NAD}^{+}$and $\mathrm{Mg}^{2+}$ (Table 3). The presence of the relatively high concentration of ATP $(6.7 \mathrm{mM})$ in the incubation mixtures was necessary since extracts possessed adenosine triphosphatase activity $(5 \mathrm{nmol} /$ min per $\mathrm{mg}$ of protein). The extracts also possessed a relatively high NADH oxidase activity $(13 \mathrm{nmol} /$ min per mg of protein) which was sufficient to maintain NAD in the oxidized state during thiophen-2carboxylate degradation. Freshly prepared extracts had a specific activity with respect to thiophen-2carboxylate degradation of $20-30 \mathrm{nmol}$ of ${ }^{14} \mathrm{CO}_{2}$ evolved/h per $\mathrm{mg}$ of protein, but approx. $50 \%$ of this activity was lost after storage at $4^{\circ} \mathrm{C}$ for $24 \mathrm{~h}$. Overnight dialysis against $50 \mathrm{~mm}$-Tris- $\mathrm{HCl}$ buffer $(\mathrm{pH}$ 7.75) resulted in a further decrease in activity.

Thiophen-2-carboxylate-degrading activity was more than doubled by the addition of Methylene Blue $(2 \mu \mathrm{mol})$ to the reaction mixture. Phenazine methosulphate at the same concentration had little effect on the system, but ferricyanide and 2,6-dichlorophenol-indophenol were inhibitory. This stimulation of activity by Methylene Blue suggested a requirement for an electron-transport system and evidence that this was of a particulate nature was obtained by centrifuging at $140000 \mathrm{~g}$ for $2 \mathrm{~h}$. This resulted in a decrease in the activity of the supernatant fraction (Table 4), but activity was increased markedly by the addition of Methylene Blue or the $140000 \mathrm{~g}$ pellet. The high-speed pellet retained thiophen-2-carboxylate-degrading activity, but this was not significantly stimulated by Methylene Blue. This result indicated that the complete thiophen-2-carboxylate-degrading system involves soluble and insoluble fractions. The activity of the $140000 \mathrm{~g}$ pellet may be due to residual soluble enzymes remaining after the supernatant was removed, whereas the remaining activity of the high-speed supernatant is probably due to the centrifuging procedure being insufficient to sediment all the particulate materials.

Further evidence that 2-oxoglutarate was involved in the sequence of biochemical events involved in the degradation of thiophen-2-carboxylate was obtained by including glutamate dehydrogenase in the cell-free system. This reaction also requires NADH but, owing presumably to the high NADH oxidase activity of extracts, incubations in which only glutamate dehydrogenase $(0.1 \mathrm{mg})$ and NADH $(1.5 \mu \mathrm{mol})$ were added to the reaction mixture resulted in very little decrease in ${ }^{14} \mathrm{CO}_{2}$ release. Inclusion of an
Table 4. High-speed fractionation of the thiophen-2carboxylate-degrading system of Organism $R 1$

A sample of $20000 \mathrm{~g}$ extract $(7 \mathrm{ml})$ was centrifuged at $0^{\circ} \mathrm{C}$ for $2 \mathrm{~h}$ at $140000 \mathrm{~g}$ and the supernatant removed. The pellet was resuspended in $7 \mathrm{ml}$ of $50 \mathrm{~mm}$-Tris$\mathrm{HCl}$ buffer, $\mathrm{pH} 7.75$, and each fraction assayed for thiophen-2-carboxylate degradation. Methylene Blue $(2 \mu \mathrm{mol})$ was included in the assay mixture where indicated. The protein concentrations of the fractions were: $20000 \mathrm{~g}$ extract, $12.2 \mathrm{mg} / \mathrm{ml} ; 140000 \mathrm{~g}$ supernatant, $11.8 \mathrm{mg} / \mathrm{ml} ; 140000 \mathrm{~g}$ pellet, $3.1 \mathrm{mg} / \mathrm{ml}$. Equal volumes $(0.5 \mathrm{ml})$ of each fraction were used in the assay mixtures. Specific radioactivities (c.p.m./h per $\mathrm{mg}$ of protein) are given in parentheses.

$$
\begin{gathered}
{ }^{14} \mathrm{CO}_{2} \text { evolved } \\
\text { (c.p.m./h per assay mixture) }
\end{gathered}
$$

\begin{tabular}{|c|c|c|}
\hline Protein fraction & $\begin{array}{l}\text { Without } \\
\text { Methylene } \\
\text { Blue }\end{array}$ & $\begin{array}{l}\text { With } \\
\text { Methylene } \\
\text { Blue }\end{array}$ \\
\hline $\begin{array}{l}20000 \mathrm{~g} \text { extract } \\
140000 \mathrm{~g} \text { supernatant } \\
140000 \mathrm{~g} \text { pellet }\end{array}$ & $\begin{array}{l}1126(185) \\
258(44) \\
287(185)\end{array}$ & $\begin{array}{r}2780(455) \\
1744(296) \\
337(218)\end{array}$ \\
\hline
\end{tabular}

$140000 \mathrm{~g}$ supernatant $909(122)$

$+140000 \mathrm{~g}$ pellet

NADH-generating system consisting of ethanol $(10 \mu \mathrm{mol})$ and ethanol dehydrogenase $(1.5 \mathrm{mg})$, overcame this problem. Ethanol itself was inhibitory to the thiophen-2-carboxylate-degrading system but when glutamate dehydrogenase was also present a further $60 \%$ decrease in ${ }^{14} \mathrm{CO}_{2}$ evolution was observed.

The direct conversion of thiophen-2-carboxylate into 2-oxoglutarate by extracts was demonstrated in incubations containing ATP, $\mathrm{CoA}, \mathrm{MgCl}_{2}$, Methylene Blue and arsenite (2mM). This reaction was shown to occur under anaerobic conditions (see the Experimental section). The identity of the 2-oxoglutarate was confirmed by co-chromatography of its 2,4dinitrophenylhydrazone with authentic material in solvents TL 4 and TL 5 . These results indicate that 2-oxoglutarate is an intermediate of thiophen-2carboxylate dissimilation and that its conversion into this keto acid does not involve an oxygenase reaction.

The enzymes that effect thiophen-2-carboxylate degradation were induced specifically by growth of the organism on this substrate. Extracts prepared from cultures grown on succinate or furan-2-carboxylate produced ${ }^{14} \mathrm{CO}_{2}$ from thiophen-2-[ $\left[{ }^{14} \mathrm{C}\right] \mathrm{carb}-$ oxylate at rates of the order of $1 \mathrm{nmol} / \mathrm{h}$ per $\mathrm{mg}$ of protein. Activity was not significantly increased by the addition of Methylene Blue. 


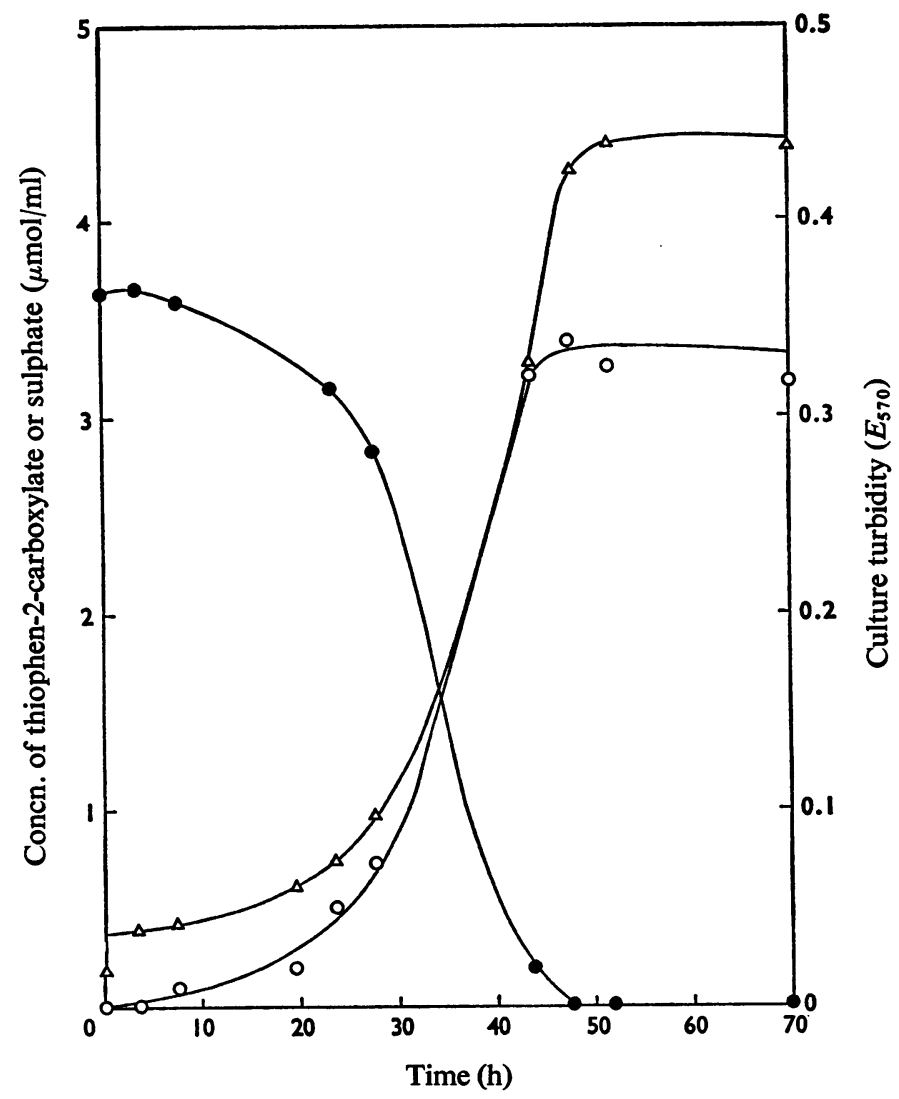

Fig. 1. Conversion of the sulphur atom of thiophen-2-carboxylate into sulphate by growing cultures of Organism $R 1$

Samples $(20 \mathrm{ml})$ were taken at intervals from cultures of Organism R1 growing on thiophen-2-carboxylate and the culture turbidity was determined at $E_{570}(\Delta)$. Cells were removed by centrifuging $(20000 \mathrm{~g}, 5 \mathrm{~min})$ and thiophen-2-carboxylate was determined in the supernatant $(\bullet)$. Supernatants were extracted twice with $5 \mathrm{ml}$ of ether and the aqueous layers were passed through a column $(4 \mathrm{~cm} \times 0.5 \mathrm{~cm})$ of Dowex- $50 \mathrm{~W}$ ion-exchange resin (X8; 50-100 mesh; $\mathrm{H}^{+}$form). The effluents were re-extracted with ether and the aqueous layers adjusted to pH4.0 with $\mathrm{NH}_{3}$ and analysed for sulphate $(0)$. Sulphate values are corrected for the amount present at zero time $(0.5 \mu \mathrm{mol} / \mathrm{ml})$.

\section{Formation of CoA ester of thiophen-2-carboxylate}

The requirements for ATP and CoA in the metabolism of thiophen-2-carboxylate by crude extracts suggested that the formation of a CoA ester might be an essential step during degradation. Attempts to trap such a compound were made by incubating $20000 \mathrm{~g}$ extract $(12.1 \mathrm{mg}$ of protein), supplemented with ATP $(20 \mu \mathrm{mol})$ and CoA $(0.52 \mu \mathrm{mol})$, with thiophen-2-[ $\left[{ }^{14} \mathrm{C}\right]$ carboxylate $(3.3 \mu \mathrm{mol}, 22 \mu \mathrm{Ci} / \mathrm{mmol})$ in $3 \mathrm{ml}$ of $50 \mathrm{~mm}$-Tris-HCl buffer (pH 7.75) containing $400 \mu \mathrm{mol}$ of neutralized hydroxylamine hydrochloride. After $3 \mathrm{~h}$ at $30^{\circ} \mathrm{C}, 2 \mathrm{mg}$ of authentic thiophen-2carbohydroxamic acid was added. The material that was soluble in aq. $66 \%(\mathrm{v} / \mathrm{v})$ ethanol was chromato- graphed in solvent TL 1 and the band that was radioactive and reacted with $\mathrm{FeCl}_{3}\left(R_{F} 0.20\right)$ was eluted. The radioactivity could not be separated from the authentic hydroxamic acid by subsequent chromatography in solvents TL 3, TL 8, TL 9 and TL 10.

The formation of this compound was dependent on the presence of ATP, CoA and $20000 \mathrm{~g}$ extract. Omission of ATP from the reaction mixture resulted in a barely detectable incorporation of radioactivity into hydroxamate. Slightly more radioactivity was detected when CoA only was omitted, but the amount was much less than in the control containing both ATP and CoA. 


\section{Metabolism of the CoA ester of thiophen-2-carboxylate}

Under anaerobic conditions, the metabolism of the $\mathrm{CoA}$ ester of thiophen-2-carboxylate by $20000 \mathrm{~g}$ extracts could be linked to Methylene Blue reduction. Endogenous Methylene Blue-reducing activity of the crude extracts obscured this process, but this was decreased by treatment of the extracts with Sephadex G-25. The rate of Methylene Blue reduction elicited by the CoA ester $(2.79 \mathrm{nmol} / \mathrm{min}$ per $\mathrm{mg}$ of protein) was not dependent on the presence of $\mathrm{NAD}^{+}$in the reaction mixture, but omission of $\mathrm{Mg}^{2+}$ resulted in a decrease in activity to $1.74 \mathrm{nmol} / \mathrm{min}$ per $\mathrm{mg}$ of protein.

\section{Formation of sulphate from thiophen-2-carboxylate}

Sulphate, identified by the i.r. spectrum of its barium salt, accumulated in cultures of Organism R1 growing on thiophen-2-carboxylate, and the appearance of sulphate closely followed the disappearance of substrate (Fig. 1). A $90 \%$ conversion of the sulphur in the substrate molecule into sulphate was obtained with growing cultures, and resting cell suspensions effected a quantitative conversion.

\section{Formation of sulphide from thiophen-2-carboxylate}

The previous result showed that sulphate was the terminal sulphur-containing compound of thiophen2-carboxylate metabolism by Organism R1. However, cells actively metabolizing thiophen-2-carboxylate during growth or in resting suspension emitted the characteristic odour of $\mathbf{H}_{2} \mathrm{~S}$. This identification was confirmed in an experiment in which air was continually passed through a suspension of thiophen-2carboxylate-grown cells $(80 \mathrm{mg}$ dry wt.) in $30 \mathrm{ml}$ of $67 \mathrm{~mm}$-phosphate buffer, $\mathrm{pH} 8.0$, containing thiophen2-carboxylate $(50 \mu \mathrm{mol})$ and chloramphenicol $(3 \mathrm{mg})$. The exhaust gas was passed through a solution of $N$-ethylmaleimide (10 mM in $67 \mathrm{~mm}$-phosphate buffer, pH 7.2). Chromatography of samples of this solution in solvents TL 1, TL 8, TL 10 and TL 11 revealed the presence of a $\mathrm{N}$-ethylmaleimide derivative with a mobility identical with that of the authentic $\mathrm{H}_{2} \mathrm{~S}$ derivative. $\mathrm{H}_{2} \mathrm{~S}$ was identified by this method in the head-space gases above cells metabolizing thiophen2-carboxylate after growth not only on this substrate but also on succinate and succinate + thiophen-3carboxylate $(100 \mu \mathrm{M})$. Control incubations lacking substrate did not release $\mathrm{H}_{2} \mathrm{~S}$.
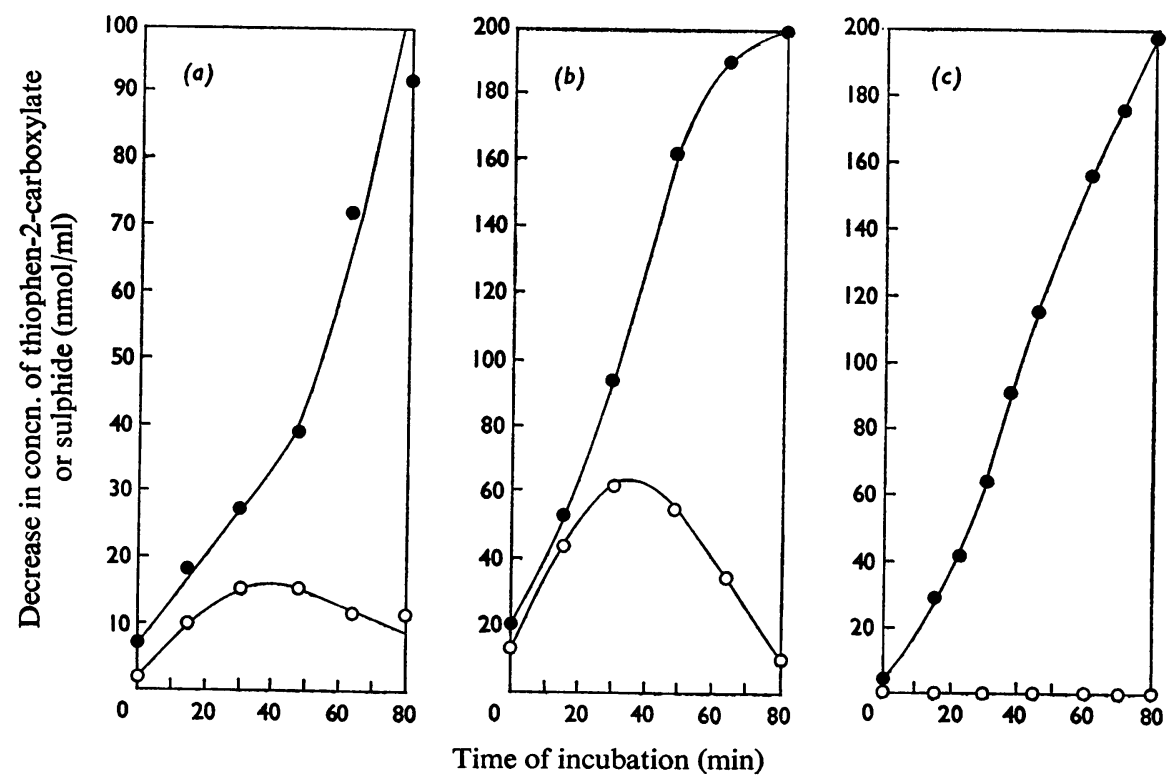

Fig. 2. Sulphide formation during thiophen-2-carboxylate metabolism by washed cell suspensions of Organism R1

Washed cells from the various cultures were incubated with shaking at $30^{\circ} \mathrm{C}$ in $25 \mathrm{ml}$ of $67 \mathrm{~mm}$-phosphate buffer (pH 8.0) containing $5 \mu \mathrm{mol}$ of thiophen-2-carboxylate. Samples $(3 \mathrm{ml})$ were removed at intervals and centrifuged $(20000 \mathrm{~g}, 5 \mathrm{~min})$ and the supernatants were analysed for thiophen-2-carboxylate $(\bullet)$ and sulphide (0). (a) Succinate-grown cells $(43 \mathrm{mg}$ dry wt.); (b) succinate + thiophen-3-carboxylate $(0.1 \mathrm{~mm})$-grown cells $(32 \mathrm{mg}$ dry wt.); (c) thiophen-2-carboxylate-grown cells ( $14 \mathrm{mg}$ dry wt.). 


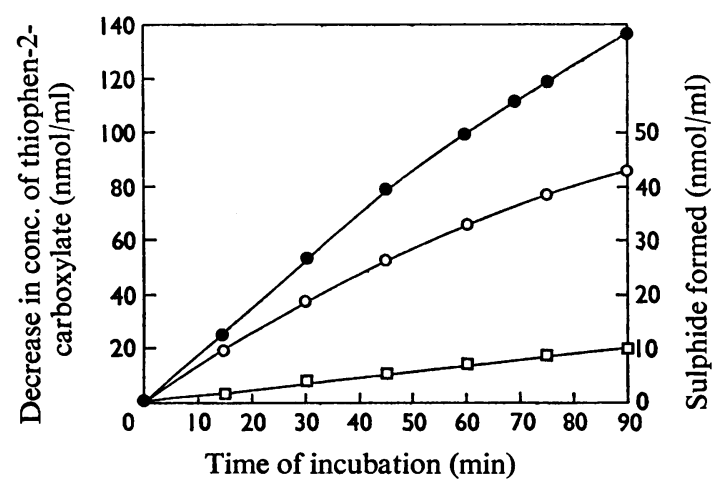

Fig. 3. Sulphide formation from thiophen-2-carboxylate in cell suspensions of Organism $R 1$ grown on thiophen-2-carboxylate, incubated in the presence of 5,5'-dithiobis-(2-nitrobenzoic acid)

Sulphide formation ( 0 ) was followed in a reaction mixture containing $5 \mu \mathrm{mol}$ of thiophen-2-carboxylate, $5 \mu \mathrm{mol}$ of 5,5'-dithiobis-(2-nitrobenzoic acid) (Ellman's reagent) and $8 \mathrm{mg}$ of thiophen-2-carboxylategrown washed cells in $25 \mathrm{ml}$ of $67 \mathrm{mM}$-phosphate buffer (pH 8.0). Endogenous sulphide formation ( $\square$ ) was followed in a similar reaction mixture lacking substrate. Thiophen-2-carboxylate disappearance (๑) was followed in a parallel incubation from which the Ellman's reagent was omitted. Samples $(3 \mathrm{ml})$ were removed from the three incubations at intervals and centrifuged $(20000 \mathrm{~g}, 5 \mathrm{~min})$. Sulphide concentration was determined from measurements of $E_{412}$ of the supernatants which were compared with a standard solution prepared with known amounts of sulphide.

Only approx. $10 \%$ of the $\mathrm{H}_{2} \mathrm{~S}\left(\mathrm{p} K_{a} 7.04\right)$ produced by the system will be present in the undissociated form at pH8.0. Hence determinations of the amounts of $\mathrm{H}_{2} \mathrm{~S}$ appearing in the gaseous phase will not give an accurate measure of the total amount being produced. Sulphide was therefore determined in samples of the aqueous suspensions of cells metabolizing thiophen-2-carboxylate. Typical results are shown in Fig. 2 for cells grown on succinate, succinate + thiophen-3-carboxylate and thiophen-2-carboxylate. Sulphide was not detected at any time during the metabolism of thiophen-2-carboxylate-grown cells (Fig. $2 c$ ) even though $\mathrm{H}_{2} \mathrm{~S}$ had been identified in the gaseous phase above similar incubations. Succinate-grown cells (Fig. 2a) exhibited a low $(0.39 \mu \mathrm{mol} / \mathrm{min}$ per $\mathrm{mg}$ dry wt.) ability to metabolize thiophen-2-carboxylate and sulphide accumulated during the first $45 \mathrm{~min}$ at a rate comparable with the rate of disappearance of substrate, but then reached a maximum and declined in concentration. Similar behaviour was exhibited by cells grown in the presence of thiophen-3-carboxylate (Fig. 2b) except that the rates of substrate degradation $(1.93 \mu \mathrm{mol} /$ min per mg dry wt.) and sulphide accumulation and subsequent disappearance were much greater. The presence of chloramphenicol $(0.1 \mathrm{mg} / \mathrm{ml})$ did not alter this behaviour substantially. Substrate-free control incubations showed no sulphide accumulation. The non-zero sulphide concentrations found at the earliest sampling time are presumably due to metabolic activity during the centrifuging of the samples.

The discrepancy between the identification of $\mathrm{H}_{2} \mathrm{~S}$ in the gaseous phase above thiophen-2-carboxylategrown cells during thiophen-2-carboxylate metabolism and the non-appearance of sulphide in the liquid medium was examined further. Reaction mixtures were set up containing Ellman's (1959) reagent [5,5'-dithiobis-(2-nitrobenzoic acid)], so that any sulphide formed would be immediately trapped. Since the presence of Ellman's reagent interfered with thiophen-2-carboxylate determinations the rate of substrate disappearance in this system was determined in parallel incubations lacking the reagent since it had been shown that concentrations of this reagent up to $1 \mathrm{~mm}$ had little effect on the rate of oxidation of thiophen-2-carboxylate. The results (Fig. 3) showed that a thiol compound, presumably sulphide, appears in the incubation medium as thiophen-2-carboxylate is degraded although stoicheiometric amounts are not trapped by this procedure. Control incubations lacking substrate showed only low sulphide accumulation.

\section{Discussion}

The results presented allow a scheme to be proposed for the route of thiophen-2-carboxylate degradation. This is shown in Scheme 1. Several distinct pieces of evidence show that thiophen-2-carboxylate is converted into 2-oxoglutarate. Thus, this keto acid was shown to accumulate in arsenite-inhibited resting cell suspensions, and studies with radioactively labelled thiophen-2-carboxylate showed that the 2oxoglutarate had the same specific radioactivity as the substrate, indicating that it was formed directly from thiophen-2-carboxylate. Besides this evidence from resting cells, 2-oxoglutarate was shown indirectly to be an intermediate during growth. The inclusion of thiophen-2-[ $\left.{ }^{14} \mathrm{C}\right]$ carboxylate in the growth medium resulted in only three amino acids of the cellular proteins, proline, arginine and glutamate, becoming labelled and these compounds had the same specific radioactivity as the substrate. The study of many microbial species has shown that these three amino acids are all derived from 2-oxoglutarate, glutamate arising either by direct transamination of this keto acid or by the glutamate dehydrogenase reaction and proline and arginine being formed from further transformations of glutamate. No other amino 

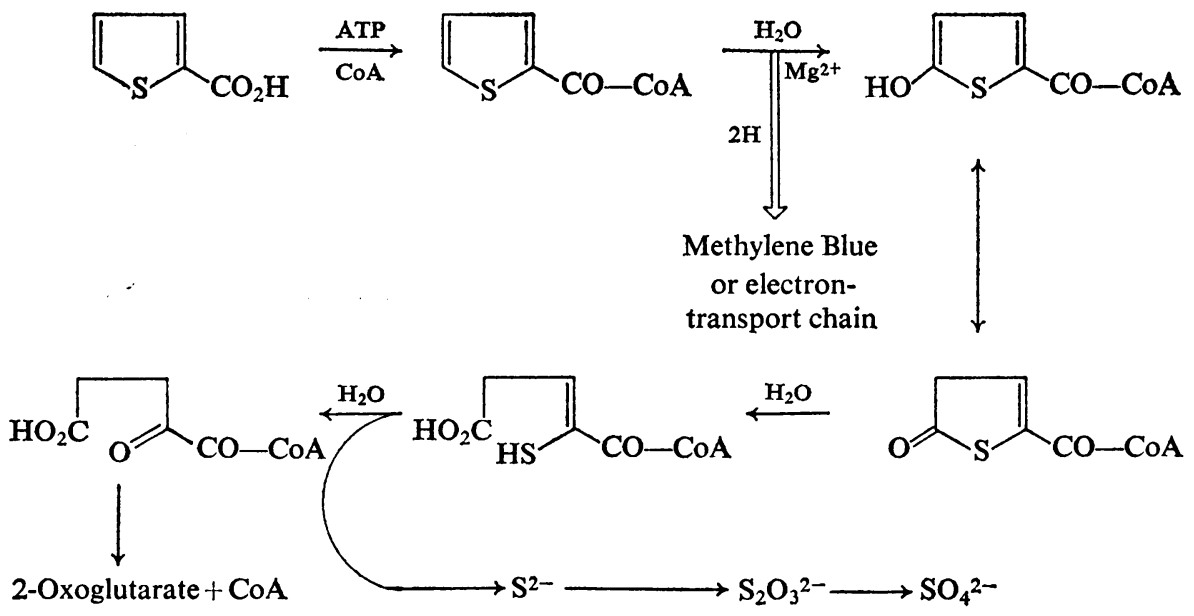

Scheme 1. Proposed route of thiophen-2-carboxylic acid degradation by organism $R 1$

acid would be expected to become labelled if the ${ }^{14} \mathrm{C}$ atom of thiophen-2-carboxylate (the carboxyl carbon atom) became $\mathrm{C}-1$ of 2-oxoglutarate, as this atom would be lost as $\mathrm{CO}_{2}$ by the 2-oxoglutarate dehydrogenase reaction. Evidence that this was the case was obtained by partial degradation of the glutamate when all the radioactivity was found in C-1 of this molecule. Thus the carboxyl group of thiophen-2carboxylate becomes C-1 of glutamate and this implies that this carbon atom becomes $\mathrm{C}-1$ of 2-oxoglutarate.

The method of assay of thiophen-2-carboxylate breakdown by cell-free extracts was based on the assumption that 2-oxoglutarate was formed and the $\mathrm{C}-1$ atom was released as $\mathrm{CO}_{2}$ by the 2-oxoglutarate dehydrogenase reaction. This assumption was supported by the fact that the process was inhibited by arsenite and under these conditions 2-oxoglutarate accumulated. In addition the inclusion of glutamate dehydrogenase in the assay system resulted in a decrease in the rate of $\mathrm{CO}_{2}$ evolution, indicating that the $\mathrm{CO}_{2}$ arises from 2-oxoglutarate.

The intermediate steps leading to 2-oxoglutarate formation are not clearly understood. The first step, the formation of a CoA ester, was deduced from the observation that CoA and ATP were stimulatory to the evolution of $\mathrm{CO}_{2}$ from thiophen-2-carboxylate by cell-free extracts. Incubations which included hydroxylamine resulted in the formation of the hydroxamic acid derivative of thiophen-2-carboxylate and this reaction was dependent on the presence of ATP, CoA and cell-free extract. Hence all the requirements for the formation and detection of a CoA ester are satisfied in this system and it can be concluded that this reaction is the first step in the sequence. Confirmation of this was obtained from the observation that synthetic thiophen-2-carboxylate CoA ester was metabolized by extracts of the organism.

None of the subsequent steps shown in Scheme 1 have been fully characterized. The stimulation of $\mathrm{CO}_{2}$ release by Methylene Blue with $20000 \mathrm{~g}$ extract and the reduction of this dye by thiophen-2-carboxylate CoA ester show that a system of electron transport to oxygen is required and that the rate of thiophen2-carboxylate degradation in the absence of Methylene Blue is limited by the rate of electron transport. The natural electron-transport system was shown to be particulate, since $140000 \mathrm{~g}$ supernatant was virtually devoid of thiophen-2-carboxylate-metabolizing activity. Activity was increased by the addition of $140000 \mathrm{~g}$ pellet or of Methylene Blue. Hence the system must be considered to consist of soluble and insoluble fractions, the soluble fraction catalysing the conversion of thiophen-2-carboxylate into 2oxoglutarate and the particulate fraction acting as a transport system for the electrons produced during the conversion. The optimum ratio of soluble to particulate fractions is not attained in the $20000 \mathrm{~g}$ extract, since activity is stimulated by the addition of Methylene Blue.

The generation of electrons during thiophen-2carboxylate metabolism and the fact that the conversion of this compound into 2-oxoglutarate can occur under anaerobic conditions suggests the participation of a hydroxylating step in which the oxygen atom is derived from water rather than molecular $\mathrm{O}_{2}$. Similar hydroxylating systems of microbial origin have been described for nicotinic acid (Hunt et al., 1958), picolinic acid (Dagley \& Johnson, 1963) and furan-2-carboxylate (Trudgill, 1969). The latter system would appear to be closely 
similar to the thiophen-2-carboxylate-degrading system, since the substrate for the hydroxylation reaction is not the free acid but its CoA ester and the electrons from the reaction are transported to oxygen by a particulate system which can be replaced by Methylene Blue. With the pyridine carboxylic acids, CoA has not been shown to be involved and other electron carriers besides Methylene Blue can replace the particulate fraction in the hydroxylation reaction. No hydroxylated thiophen derivative was identified during the present work, and the inclusion of 5-hydroxythiophen-2-carboxylic acid CoA thioester in the proposed degradative sequence is not supported by rigorous experimental evidence. Hence the remaining intermediates shown in Scheme 1 are completely hypothetical. In particular CoA is shown as being released by hydrolytic cleavage of 2-oxoglutaryl-CoA, but it is conceivable that this cleavage could occur at any stage after the introduction of the hydroxyl group. The work of Amphlett (1968) indicates the possibility that CoA is released immediately after the hydroxylation reaction, since extracts of his organism were capable of effecting the conversion of 5-hydroxythiophen-2-carboxylate into 2-oxoglutarate. However, Amphlett (1968) did not implicate CoA in the degradation of thiophen-2carboxylate and the reactions occurring in his system may be different from those occurring in Organism R1.

The end product of the metabolism of the sulphur atom of thiophen-2-carboxylate by Organism R1 is sulphate. In this respect it differs markedly from the flavobacterium used by Amphlett (1968), which released the sulphur atom as sulphide. Sulphide would appear to be an intermediate of thiophen-2-carboxylate degradation by Organism R1, since it was oxidized by cells grown on thiophen-2-carboxylate and was produced during the metabolism of this compound. The amounts of sulphide formed in cell suspensions, however, were dependent on the growth substrate of the cells and when grown on thiophen-2carboxylate little sulphide accumulated and sulphate was formed. When cells were grown on succinate or succinate + thiophen-3-carboxylate more sulphide was produced, the rate of appearance of this compound being equal to the rate of disappearance of the substrate during the initial stages of the reaction. The interpretation of this result is that succinate alone or succinate + thiophen-3-carboxylate does not induce the enzymes necessary for the transformations of inorganic sulphur compounds. Hence cells grown under these conditions should convert all the sulphur of thiophen-2-carboxylate into sulphide. This condition is virtually fulfilled during the initial stages of the reaction. The maxima in sulphide concentration observed in the latter stages of this reaction are probably not due to induced synthesis of enzymes capable of the metabolism of sulphide, since a similar maximum is obtained when chloramphenicol is included, and this behaviour is probably explained by the spontaneous oxidation of the compound. When the cells are grown on thiophen-2-carboxylate the ability to oxidize sulphide is induced and its accumulation is decreased. Oxidation of sulphide is shown in Scheme 1 to proceed to sulphate via thiosulphate. The inclusion of this compound is based solely on the observation that the ability to oxidize this compound is associated with cells grown on thiophen-2-carboxylate or on succinate+sulphide, whereas this activity was virtually lacking from cells grown on all other substrates tested. This is strongly suggestive of thiosulphate being an intermediate of the pathway, but is not conclusive evidence.

In all particular aspects the transformations of the carbon skeleton of thiophen-2-carboxylate shown in Scheme 1 resemble those proposed by Trudgill (1969) for furan-2-carboxylate metabolism by Pseudomonas F2. Since Organism R1 is also capable of utilizing furan-2-carboxylate as a carbon substrate for growth, it is probable that a sequence of enzyme reactions very similar to those shown by Trudgill (1969) operates in this organism also. It is possible that some analogous steps of the transformations of thiophen2-carboxylate and furan-2-carboxylate are catalysed by the same enzymes, but specific enzymes are involved as is shown by the inductive responses under different growth conditions. Thus growth on thiophen-2-carboxylate resulted in cells able to oxidize both heterocyclic acids whereas growth on furan-2carboxylate resulted in only the ability to oxidize the growth substrate. In addition, thiophen-3-carboxylate induced the capacity to oxidize both substrates. Specific permeases may play some role, but enzymes specific for furan-2-carboxylate breakdown only are induced by growth on this compound, since extracts from these cells are unable to catalyse the release of $\mathrm{CO}_{2}$ from thiophen-2-carboxylate. It must be concluded that the thiophen carboxylic acids induce the synthesis of enzymes of the degradative pathways of both substrates whereas furan-2-carboxylate only induces the enzymes that catalyse its own dissimilation. Hence each pathway is under separate control.

A third set of enzymes which are under independent control are also involved, namely those required for the transformations of inorganic sulphur compounds. In the present work this activity was equated with the ability of cells to oxidize thiosulphate. It was induced by thiophen-2-carboxylate but not by thiophen-3carboxylate. The actual inducer is most probably an inorganic sulphur compound since growth in the presence of sulphide resulted in the appearance of this activity.

I thank Professor J. W. Cornforth and Dr. H. J. Somerville for their stimulating criticism.

Vol. 134 


\section{References}

Altmann, S. M., Crook, E. M. \& Datta, S. P. (1951) Biochem. J. 49, lxiii

Amphlett, M. J. (1968) Ph.D. Thesis, University of Cardiff Amphlett, M. J. \& Callely, A. G. (1969) Biochem. J. 112, $12 P$

Beaven, G. H., Holiday, E. R. \& Johnson, E. A. (1955) in The Nucleic Acids (Chargaff, E. \& Davidson, J. N., eds.), vol. 1, p. 493, Academic Press, New York

Benesch, R., Benesch, R. E., Gutcho, M. \& Lawfer, L. (1956) Science 123, 981

Benkeser, R. A. \& Currie, R. B. (1948) J. Amer. Chem. Soc. 70, 1780-1782

Bertolacini, R. J. \& Barney, J. E. (1957) Anal. Chem. 29, 281-283

Bray, G. A. (1960) Anal. Biochem. 1, 279-285

Cavallini, D., Frontali, N. \& Toschi, G. (1949) Nature (London) 163, 568-569

Challenger, F. (1959) Aspects of the Organic Chemistry of Sulphur, pp. 73-114, Butterworths Scientific Publications, London

Chen, P. S., Toribara, T. Y. \& Warner, H. (1956) Anal. Chem. 28, 1756-1758

Cripps, R. E. (1971) Ph.D. Thesis, University of Warwick

Dagley, S. \& Johnson, P. A. (1963) Biochim. Biophys. Acta 78, 577-587

Dancis, J., Hutzler, J. \& Levitz, M. (1963) Biochim. Biophys. Acta 78, 85-90

Druschel, H. V. \& Sommers, A. L. (1967) Anal. Chem. 39, 1819-1829

Ellman, G. L. (1959) Arch. Biochem. Biophys. 82, 70-77

Gianturco, M. A., Giammarino, A. S. \& Friedel, P. (1966) Nature (London) 210, 1358

Gronowitz, S. (1963) Advan. Heterocycl. Chem. 1, 1-124

Gross, D. (1955) Nature (London) 176, 72-73

Hoare, D. S. (1963) Biochem. J. 87, 284-301

Hockenhull, D. J. D., Hunter, G. D. \& Herbert, M. W. (1953) Chem. Ind. (London) 127

Hunt, A. L., Hughes, D. E. \& Lowenstein, J. M. (1958) Biochem. J. 69, 170-173
Jones, L. W. \& Hurd, C. D. (1921) J. Amer. Chem. Soc. 43, 2422-2448

Kemble, A. R. \& MacPherson, H. T. (1954) Biochem. J. $56,548-555$

Kodama, K., Nakatani, S., Umehara, K., Shimizu, K., Minoda, Y. \& Yamada, K. (1970) Agr. Biol. Chem. 34, 1320-1324

Kurita, S., Endo, T., Nakamura, H., Yagi, T. \& Tamiya, N. (1971) J. Gen. Appl. Microbiol. 17, 185-198

Lapidot, Y., Rappoport, S. \& Wolman, Y. (1967) J. Lipid Res. 8, 142-145

Leggett Bailey, J. (1967) Techniques in Protein Chemistry, 2nd edn., pp. 1-60, Elsevier Amsterdam, London and New York

Lowry, O. H., Rosebrough, N. J., Farr, A. L. \& Randall, R. J. (1951) J. Biol. Chem. 193, 265-275

Murray, A. \& Williams, D. L. (1958) Organic Synthesis with Isotopes, part 1, p. 86, Interscience Publications, London and New York

Petrowitz, H. J. \& Pastuska, G. (1962) J. Chromatogr. 7, 128-130

Price, C. A. \& Campbell, C. W. (1957) Biochem. J. 65, 512-516

Rockstein, M. \& Herron, P. W. (1951) Anal. Chem. 23, 1500-1501

Ronkainen, P. (1963) J. Chromatogr. 11, 228-237

Ryle, A. P., Sanger, F., Smith, L. F. \& Kitai, R. (1955) Biochem. J. 60, 541-556

Somerville, H. J. (1965) Ph.D. Thesis, University of Sheffield

Stoll, M., Winter, M., Gautschi, F., Flament, I. \& Willhalm, B. (1967) Helv. Chim. Acta 50, 628694

Thompson, C. J., Coleman, H. J., Hopkins, R. L. \& Rall, H. T. (1965) Am. Soc. Test. Mater. Spec. Tech. Publ. 389, 329

Trudgill, P. W. (1969) Biochem. J. 113, 577-587

Vogel, A. I. (1961) A Textbook of Quantitative Inorganic Analysis, 3rd edn., p. 277, Longmans, London

Yamada, K., Minoda, Y., Kodama., Nakatani, S. \& Abasaki, T. (1968) Agr. Biol. Chem. 32, 840-845 